\title{
What Welfare States Do: A Disaggregated Expenditure Approach ${ }^{1}$
}

\author{
FRANCIS G. CASTLES
}

Research School of Social Sciences, Australian National University, Canberra
email: castles@coombs.anu.edu.au

\begin{abstract}
This article suggests that an alternative to a social rights of citizenship approach to comparing welfare states is to use disaggregated programme expenditure data to identify the diverse spending priorities of different types of welfare state. An initial descriptive analysis shows that four major categories of social spending (cash spending on older people and those of working age; service spending on health and for other purposes) are almost entirely unrelated to one another and that different welfare state regimes or families of nations exhibit quite different patterns of spending. The article proceeds to demonstrate that both the determinants and the outcomes of these different categories of spending also differ quite radically. In policy terms, most importantly, the article shows that cross-national differences in poverty and inequality among advanced nations are to a very large degree a function of the extent of cash spending on programmes catering to the welfare needs of those of working age.
\end{abstract}

\section{On aggregate expenditure measures}

In what is unquestionably the single most influential account of variation in the nature of Western welfare states, Gøsta Esping-Andersen offers a critique of aggregate social spending as a measure for comparing the size and success of welfare states. His argument is that 'by scoring welfare states on spending, we assume that all spending counts equally' (Esping-Andersen, 1990: 19), and that this is manifestly not the case in respect of the items together constituting total public social expenditure. As examples of the kinds of items which should not properly be counted as welfare effort, he adduces high spending on benefits for privileged Austrian civil servants, fiscal welfare for the middle classes, disproportionate spending on means-tested social assistance, and spending occasioned by extremely high unemployment, as in Margaret Thatcher's Britain. These items of expenditure variously reward those who are already well off, stigmatise those in receipt of benefits or are occasioned only by the failure of the state to intervene in the first instance. All are putatively instances of spending which fail to extend the realm of social citizenship, which Esping-Andersen, following Richard Titmuss (1950), sees as 'the core idea of the welfare state' (Esping-Andersen, 1990). 
However, even where - as in the poverty and social exclusion research that has been such an important part of Stephan Leibfried's contribution to social policy scholarship (see Leibfried, 1993; Buhr and Leibfried, 1995; Leisering and Leibfried, 1999) - the underlying conception is the simpler and more traditional one of alleviating poverty and inequality, a similar argument remains appropriate. Expenditures favouring the privileged and the middle classes do not have the same welfare-conferring status as those favouring the poor and the underprivileged. Here, expenditures on social assistance and on unemployment benefits do, indeed, count for more than spending on benefits for the already comfortably situated. However, that only underlines precisely the same point: that, in measuring what welfare states do, aggregate 'expenditure is not enough' (Castles, 1994), because not all spending counts the same.

Esping-Andersen's solution to the problem of the incommensurability of different types of welfare spending is to measure the size and success of welfare states by a different yardstick: namely, the extent to which welfare state benefits provide 'de-commodified' social rights of citizenship. In effect, what this amounts to is a measure, not of the size of aggregate state spending, but of the eligibility criteria by which individuals qualify as beneficiaries of the welfare state and the generosity with which these individuals are treated. Of these, the manner of provision is the more important. Esping-Andersen's three worlds of welfare capitalism are essentially a 'liberal' world of means-testing, a 'conservative' world of status-preserving social insurance and a 'social democratic' world of universalism. Generosity, which of course brings expenditure back in by the back door, is a secondary dimension. Means-tested systems are mean to everyone, social insurance is particularly generous to those with higher incomes (such as privileged Austrian civil servants) and universalism, although in its contemporary form often married to earnings replacement, is most relatively generous to working families.

Comparing welfare states in terms of their levels of de-commodification neatly sidesteps the problems involved in aggregating incommensurable types of spending by focusing on the basis of the acquisition and the extent of social rights by individuals. Arguably, however, the move to an approach focusing on social rights is not the only, or indeed even the most theoretically obvious, response to the demonstration that expenditure aggregation involves bringing together categories of spending that are not strictly comparable in terms of their purposes. If the problem is the aggregation of unlike categories of spending, the seemingly sensible way forward is to avoid an inappropriate elision of spending categories in the first instance or to group categories of spending together only where it is demonstrable that they have significant things in common. In other words, rather than look at spending aggregates, we should be disaggregating our expenditure data to such a level that we can ask meaningful questions about the consequences of spending of particular types and about the reasons 
why some countries spend more on some types of welfare state activity than others.

However, even if the adoption of a disaggregated expenditure approach could be seen as one possible response to Esping-Andersen's expenditure critique, in practical terms it was a response unavailable at the time he wrote. Until the late 1990s, the only routinely published expenditure series were for the big aggregates of total social expenditure, total social security spending and total health expenditure. Only with the first publication of the OECD Social Expenditure Database (SOCX) and, still more recently, with the development of a comparable Eurostat database for EU member states have scholars had access to expenditure data at programme level or been able to distinguish between spending on cash benefits and services. Hence, the Esping-Andersen critique of aggregate expenditure comparisons was a critique of the only game in town.

That situation has now changed, with the OECD now publishing annual data on spending for all the main programmes of the welfare state and on the nature of the provision afforded by each programme. As I have argued previously (Castles, 2002), the availability of such information makes it possible to articulate spending categories in many different ways depending on the focus of the investigation in hand. The aim of this essay is to move beyond this earlier, largely illustrative, discussion of the potential advantages of a disaggregated approach by demonstrating how the approach can help us to understand how different types of social programmes contribute to the attainment of particular welfare state goals and to paint a more differentiated picture of the factors shaping national welfare state spending profiles than has been previously been possible on the basis of aggregate spending data alone. The account we offer makes it clear that Esping-Andersen was correct in maintaining that aggregate expenditure comparisons can be highly misleading, but demonstrates no less clearly that to reject expenditure comparisons per se is wilfully to forgo one of the few sources of reliable information we possess concerning the working of modern welfare states. Our argument, in summary, is that the disaggregated categories that can be calculated from SOCX spending data are no less valuable than the decommodification index in providing data relevant to the 'theoretical substance of welfare states' and have the overwhelming advantage that they are derived from data routinely made available by national governments according to a standardised methodology policed by a respected international economic agency.

\section{On disaggregated expenditure types}

The earliest iteration of SOCX (OECD, 1996) distinguished between some 13 programme-based categories of social spending; the latest (OECD, 2007b) distinguishes between nine: old-age, survivors, incapacity-related, health, family, active labour market (ALMP), unemployment, housing and other social policy 
areas (largely social assistance spending). However, utilising data now available on whether programme spending takes the form of cash payments or services, this latest iteration of SOCX identifies types of spending according to whether they fall into one of four broad policy areas (OECD, 2007b: 20):

- Age-related cash (combining old-age and survivors' pensions);

- Working-age cash (comprising income support payments in respect of incapacity, unemployment, families and social assistance);

- Health (much the largest category of social services expenditure); and

- Other service expenditure (comprising all social services other than health).

It is spending in these four broad policy areas that we examine in this essay, ${ }^{2}$ with the only departure from the OECD categorisation being the inclusion of active labour market expenditure under the working-age cash rubric. The OECD (2007b: 20, note to Chart 4) argues that cash/services breakdown cannot be properly applied in this area. However, spending under this head is explicitly directed to alleviating/preventing distress in the working-age population and so we include it in that policy area rather than separating it out as a policy category in its own right or omitting it from the analysis altogether.

Table 1 provides information on spending as a percentage of GDP in 23 OECD countries in 2003 for each of these four broad policy areas as well as for total public social expenditure, the sum of spending for social policy in all four areas. Looking first at the mean values displayed in Table 1 , we note that age-related cash spending remains, as it has throughout the modern history of the welfare state, the most expensive priority of welfare spending. Health, however, has been catching up in recent decades, and income maintenance for the working-age population, until recently a bigger priority in hard economic times, now, in a period of relatively low unemployment in many OECD countries, ranks somewhat behind health, although not by any great margin. Other caring services, largely to older people (nursing homes and personal care) and to families (in particular, child care), represent newer objectives of the welfare state relating to the emergence of 'new social risks (Taylor-Gooby, 2004) and have been expanding in most OECD countries in recent decades, but their mean value is, nevertheless, still only around half that of cash spending on the working-age population.

Second, Table 1 makes it clear that the mean values for spending in most of these policy areas mask very considerable cross-national variation in expenditure levels as summarily demonstrated by high to very high coefficients of variation $(\mathrm{CV})$ in all but one instance. At one extreme Italy spends 13.8 per cent of its GDP on pensions and survivors' benefits, while Iceland spends just 2.4 per cent. The range for working-age cash is not much smaller, with Demark spending 10.4 per cent of GDP and Japan just 1.8 per cent. In absolute terms, the range for caring services is smaller - from Sweden's 7.4 per cent to Italy's 0.8 per cent - but that is in relation to a much smaller mean for other services of just 2.6 per cent 
TABLE 1. Types of welfare state expenditure as percentages of GDP, 2003

\begin{tabular}{|c|c|c|c|c|c|}
\hline & $\begin{array}{l}\text { Age-related } \\
\text { cash } \\
\text { expenditure }\end{array}$ & $\begin{array}{l}\text { Working-age } \\
\text { cash } \\
\text { expenditure }\end{array}$ & $\begin{array}{c}\text { Health } \\
\text { expenditure }\end{array}$ & $\begin{array}{l}\text { Other service } \\
\text { expenditure }\end{array}$ & $\begin{array}{l}\text { Total public } \\
\text { social } \\
\text { expenditure }\end{array}$ \\
\hline \multicolumn{6}{|c|}{ English-speaking } \\
\hline Australia & 3.4 & 5.8 & 6.2 & 2.5 & 17.9 \\
\hline Canada & $4 \cdot 4$ & 3.4 & 6.8 & 2.7 & 17.3 \\
\hline Ireland & 3.3 & 5.9 & 5.6 & 1.2 & 15.9 \\
\hline $\mathrm{NZ}$ & 4.5 & 6.1 & 6.3 & 1.1 & 18.0 \\
\hline UK & 5.5 & 4.7 & 6.7 & 3.2 & 20.6 \\
\hline USA & 6.2 & 2.3 & 6.7 & 1.0 & 16.2 \\
\hline \multicolumn{6}{|l|}{ Scandinavian } \\
\hline Denmark & 5.3 & 10.4 & 5.6 & 6.2 & 27.6 \\
\hline Finland & 5.5 & 7.6 & 5.7 & 3.7 & 22.5 \\
\hline Norway & 5.3 & 8.4 & 6.5 & 4.9 & 25.1 \\
\hline Sweden & 8.1 & 8.7 & 7.1 & 7.4 & 31.3 \\
\hline \multicolumn{6}{|c|}{ Continental W. Europe } \\
\hline Austria & 12.8 & 6.6 & 5.1 & 1.5 & 26.1 \\
\hline Belgium & 9.1 & 8.5 & 7.2 & 1.6 & 26.5 \\
\hline France & 12.0 & 6.4 & 7.6 & 2.7 & 28.7 \\
\hline Germany & 11.5 & 5.9 & 8.0 & 1.9 & 27.3 \\
\hline Netherlands & 5.1 & 7.6 & 5.8 & 2.2 & 20.7 \\
\hline \multicolumn{6}{|c|}{ Southern Europe } \\
\hline Greece & 12.3 & 2.4 & 5.0 & 1.6 & 21.3 \\
\hline Italy & 13.8 & 3.4 & 6.2 & .8 & 24.2 \\
\hline Portugal & 10.2 & 5.2 & 6.7 & 1.4 & 23.5 \\
\hline Spain & 8.2 & 5.6 & 5.2 & 1.3 & 20.3 \\
\hline \multicolumn{6}{|l|}{ Unclassified } \\
\hline Iceland & 2.4 & 4.3 & 7.2 & 4.8 & 18.7 \\
\hline Japan & 8.2 & 1.8 & 6.1 & 1.6 & 17.7 \\
\hline Luxembourg & 6.5 & 7.9 & 6.2 & 1.7 & 22.2 \\
\hline Switzerland & 6.9 & 5.8 & 6.0 & 1.8 & 20.5 \\
\hline Mean & 7.4 & 5.9 & 6.3 & 2.6 & 22.2 \\
\hline CV & 44.9 & 38.3 & 12.5 & 68.3 & 19.4 \\
\hline
\end{tabular}

Source and notes: From or calculated from OECD (2007a). Age-related cash $=$ spending on age pensions + survivors' cash benefits. Working-age cash $=$ total cash spending - age-related cash + active labour market spending (for justification of the inclusion of ALMP, see text). Health expenditure as in SOCX. Other service expenditure $=$ total service expenditure - health expenditure. Countries highlighted in grey are on or above the mean for a particular category of spending. Total social public expenditure as reported in SOCX.

of GDP. Only in respect of health spending is it possible to detect a greater similarity of pattern, with a coefficient of variation of just 12.5, a range of just 3 per cent of GDP from Greece at the bottom of the distribution to Germany at the top and no fewer than 18 countries out of 23 within one percentage point of GDP from the mean. Our later findings confirm those of earlier studies (Castles, 1998) that it is extremely difficult to identify the correlates of variation in public health spending in OECD countries. That may simply be because contemporary 
variation in this category of spending is so relatively constrained. Countries' public welfare effort in respect of health appears to be of much the same order in all advanced countries. That is not so in respect of other categories of spending.

Third, Table 1 demonstrates that the major differences in levels of spending other than health are not just a matter of some countries spending more and others less right across the board, but of quite diverse patterns of variation for each category of spending, with high-spending countries in one policy area of the welfare state often being low spenders on another and vice versa. The highlighting of countries above the mean for each category of spending in Table 1 is designed to make this visually apparent. The notion, implicit in the distinction between 'social democratic' and 'liberal' welfare state regimes, that extensive social provision in one area of social rights is likely to be replicated in others is seemingly contradicted by the fact that, among these 23 nations, only four manifest consistently high or low levels of spending across all policy areas. Sweden and France (the latter a core member of the 'conservative' world of welfare capitalism) score above the mean throughout, while Australia and Switzerland (the latter on the borderline between the 'liberal' and 'conservative' regime types) are consistently below it. All other countries have mixed outcomes, including three 'liberal' regimes (Canada, New Zealand and the UK) with two values above the mean and two 'social democratic' regimes (Denmark and Finland) with two values below the mean.

Fourth, it should be noted that, despite the general lack of consistency in expenditure levels across policy categories, there are distinct patterns or profiles of outcomes apparent among clusters of nations. Apart from highlighting big spenders, Table 1 also assigns countries to 'families of nations' along lines indicated in Castles $(1998,2004)$, a classification differing from Esping-Andersen's regime types most conspicuously in identifying a separate Southern European cluster. Table 1 shows that English-speaking (or 'liberal') welfare states have in common the fact that they are low spenders on pensions and that, in consequence, they manifest below-average levels of aggregate spending. Although the Scandinavian (or 'social democratic') countries are also not generally big spenders on pensions, their commonalities are quite different, scoring high on working-age cash, caring services and aggregate spending. Rather surprisingly, in formal terms, the continental Western European countries constitute the least coherent grouping, exhibiting commonality only in respect of high levels of working-age cash. However, this is exclusively a function of the marked reduction in spending in the Netherlands since the 1980 s and, excluding this case, this family exhibits the most consistently high spending profile of all groupings. Finally, and very interestingly in light of debates on whether the countries of Southern Europe constitute a type separate from the 'conservative' continental model (see Leibfried, 1993; EspingAndersen, 1993; Castles, 1995; Ferrera, 1996), the countries of Southern Europe are more distinctly clustered than any other family grouping, being characterised 
TABLE 2. Pearson's correlations between expenditure types

\begin{tabular}{lcccc}
\hline & $\begin{array}{c}\text { Age-related } \\
\text { cash } \\
\text { expenditure }\end{array}$ & $\begin{array}{c}\text { Working-age } \\
\text { cash } \\
\text { expenditure }\end{array}$ & $\begin{array}{c}\text { Health } \\
\text { expenditure }\end{array}$ & $\begin{array}{c}\text { Other service } \\
\text { expenditure }\end{array}$ \\
\hline Age-related expenditure & 1 & & & \\
Working-age expenditure & -0.169 & 1 & & \\
Health expenditure & 0.021 & 0.020 & 1 & 1 \\
Other services & -0.318 & $0.531^{* *}$ & 0.207 & 1 \\
Total social expenditure & $0.559^{* *}$ & $0.609^{* *}$ & 0.296 & $0.479^{*}$ \\
\hline
\end{tabular}

Notes: ${ }^{* *}$ Correlation is significant at the o.o1 level (2-tailed). ${ }^{*}$ Correlation is significant at the 0.05 level (2-tailed).

by consistently high levels of pension spending and low levels of spending on working-age cash and caring services.

The finding that countries and families of nations exhibit different patterns of spending in respect of different areas of policy is crucial to our argument, since it demonstrates that analysis concentrating its attention exclusively on aggregate spending is likely to obscure much that is going on in the areas constituting that aggregate, while simultaneously suggesting that a focus on spending patterns in those separate areas has the potential to provide us with new information about the nature, the causes and the consequences of welfare state variation. The differences in patterns of spending are, in a number of instances, quite dramatic. Look, for instance, in Table 1 at the high and low values exhibited for age-related cash and other services. Only nine values coincide, with low or high spending in one policy area being matched by low or high spending in the other. In 14 instances, high values in one area are matched with low values in the other, suggesting the possibility that these dimensions of welfare spending may actually be negatively related; that is, that there could be a systemic trade-off between high levels of age-related cash and low levels of expenditure on services either to older people or to families.

Table 2, which presents correlation coefficients between the various areas of expenditure and between each area and total public social expenditure, offers further support for the diverse character of social spending patterns in different nations. It shows that cash spending on older people is, in fact, unrelated to spending on any other category of social provision: that, as suspected, the relationship between age-related spending and other services is negative; and that, although not as strong, so too is the relationship between age-related and working-age spending. However, since neither of these relationships is statistically significant, the possibility of a systematic trade-off relationship is not confirmed (but see the subsequent discussion of the impact of population ageing on agerelated and working-age cash for an analogous and highly significant finding). 
The relationship between age-related expenditure and health spending is not negative, but is utterly negligible, challenging Doomsday scenarios of the future of the welfare state premised on a simultaneous explosion in pensions and health spending caused by population ageing (see Castles, 2004).

Nor is it just age-related spending that is tenuously associated with other categories of welfare state spending. Although relationships between spending on health and spending in other social policy areas are never negative, the positive correlations reported in Table 2 are very modest indeed. Moreover, although health constitutes the second largest area of OECD social expenditure, spending in this policy area is not significantly related to total spending as is the case in respect of all other policy areas. Obviously, that is a function of the low degree of variance of health sector spending already noted in our commentary on Table 1. Public health spending as a percentage of GDP varies relatively little from country to country, so it does not have a significant impact on the variance of cross-national total public social expenditure.

In fact, the only evidence of even a moderately strong association between social expenditure policy areas is that between working-age cash and other services. However, even the statistically significant correlation of 0.531 between these categories is indicative only of an overlap between spending patterns of around 28 per cent. That aside, the evidence of Table 2 is of categories of spending which share little of the same variance. Cross-national distributions of age-related cash expenditure, working-age cash expenditure and health expenditure - the three largest policy areas of the welfare state - appear quite unrelated to one another. Thus, an important advantage of an analysis focusing on disaggregated categories of social spending is that it helps us to understand that the answer to the question of what welfare states do is not only that some spend more than others (make a greater 'welfare effort'; see Wilensky, 1975), but also that some have quite different spending priorities from others.

\section{Factors shaping expenditure priorities}

Because the disaggregated programme data provided by SOCX is of quite recent provenance, it is scarcely surprising that the vast bulk of research on the determinants on social expenditure has focused almost exclusively on levels and changes in total public social expenditure (for surveys of this literature, see, among many others, Schmidt, 1996; Castles, 1998; Huber and Stephens, 2001; Myles and Quadagno, 2002). However, if as shown previously in this essay, the cross-national spending distributions of particular programmes are only relatively weakly linked to the pattern of overall spending and scarcely related to each other at all, it seems to follow that the conclusions of the existing literature on expenditure determinants may well not translate directly through to its component programmes or may translate through to some programmes better than to others. In this section of the essay, we seek to elaborate multivariate 
models of the determinants of both programme and total spending designed to establish the extent to which this is the case.

Each model is constituted by the same set of independent variables: the proportion of older people in the population, the strength of the post-war Left, the influence of Roman Catholicism, economic vulnerability to external trade as measured by a country's level of imports and exports, a country's recent experience of economic growth and its present level of unemployment. The models as reported in Table 3 are based on cross-sections of the 23 cases reported in Table 1. Obviously, the six independent variables analysed here do not exhaust the potential explanations of variance in aggregate social spending or its component programmes, but they do probably exhaust what can be done with a simple cross-sectional design. For those who believe that the methodological pitfalls can be safely negotiated (see Kittel, 1999), SOCX contains data enough for far more ambitious pooled time-series from 1980 onwards, allowing the effects of a much larger number of variables to be examined.

Although the independent variables analysed here are drawn from the standard literature on the determinants of total social expenditure, many of them may be seen, on reflection, as likely to be related more to some programmes than to others. That is obviously the case in respect of the age structure of the population, which is widely regarded as a factor shaping spending on both pensions and health. It applies no less obviously in the case of unemployment, which, whether through unemployment benefits or active labour market policy expenditure, should translate directly through to working-age cash spending. Economic vulnerability, whether construed as a force making for a 'race to the bottom' in social spending as in much of globalisation theory or as an incentive to policies of a kind that Katzenstein (1985) describes as 'domestic compensation', also seems most likely to impact on working-age cash, since it is those currently in the labour force who are most likely to bear the brunt of enhanced competition in the international economy. Economic growth might be expected to be negatively related to all aspects of spending, given that it is the denominator of the expenditure measures (that is, as percentages of GDP) used in all international comparisons, but more specifically negatively related to working-age cash, since low growth is the ultimate source of unemployment and adverse labour market conditions (see Castles, 2006; Castles and Obinger, 2007). Finally, it has been argued (see van Kersbergen, 1995) that the Catholic doctrine of 'subsidiarity' leads countries in which social policy is strongly influenced by the Catholic Church to favour cash benefits enhancing the autonomy of the family over social services provided directly by the state. We do not predict linkages to particular programmes in the case of Left strength, the main variable featuring in the by now huge 'politics matters' literature, although it could be argued that age-related and health expenditure programmes are less ideologically divisive than spending on the working poor and on caring services. 
TABLE 3. Regression models of types of welfare state expenditure

\begin{tabular}{lccccc}
\hline & $\begin{array}{c}\text { Age-related } \\
\text { cash } \\
\text { expenditure }\end{array}$ & $\begin{array}{c}\text { Working-age } \\
\text { cash } \\
\text { expenditure }\end{array}$ & $\begin{array}{c}\text { Health } \\
\text { expenditure }\end{array}$ & $\begin{array}{c}\text { Other service } \\
\text { expenditure }\end{array}$ & $\begin{array}{c}\text { Total public } \\
\text { social } \\
\text { expenditure }\end{array}$ \\
\hline Constant & $-9.448^{* * *}$ & $9.173^{* * *}$ & $7.960^{* * *}$ & $4.940^{*}$ & $13.172^{* * *}$ \\
Age 65+ & $(-2.323)$ & $(4.772)$ & $(4.667)$ & $(2.028)$ & $(3.496)$ \\
& $0.963^{* * *}$ & $-0.555^{* * *}$ & -0.086 & -0.245 & 0.088 \\
Left & $(3.581)$ & $(-4.113)$ & $(-0.737)$ & $(-1.477)$ & $(0.344)$ \\
Catholic & 0.025 & $0.080^{* * *}$ & -0.002 & $0.048^{* * *}$ & $0.153^{* * *}$ \\
Imex & $(1.011)$ & $(6.435)$ & $(-0.230)$ & $(3.148)$ & $(6.419)$ \\
GDP growth & $0.046^{* *}$ & -0.013 & -0.005 & $-0.030^{* * *}$ & -0.002 \\
& $(2.816)$ & $(-1.645)$ & $(-0.656)$ & $(-2.940)$ & $(-0.110)$ \\
Unemployment & -0.012 & $0.026^{* * *}$ & -0.001 & 0.008 & $0.021^{*}$ \\
& $(-0.965)$ & $(4.228)$ & $(-0.096)$ & $(1.105)$ & $(1.801)$ \\
Adj. R2 & 0.096 & $-0.735^{* * *}$ & -0.223 & $-0.350^{*}$ & $-1.206^{* * *}$ \\
& $(0.289)$ & $(-4.400)$ & $(-1.551)$ & $(-1.704)$ & $(-3.795)$ \\
& 0.023 & $.333^{* *}$ & 0.052 & 0.157 & $0.548^{* *}$ \\
& $(0.086)$ & $(2.537)$ & $(0.464)$ & $(0.972)$ & $(2.193)$ \\
& $\mathbf{0 . 6 6 3}$ & $\mathbf{0 . 8 0 3}$ & $-\mathbf{0 . 1 7 3}$ & $\mathbf{0 . 5 3 4}$ & $\mathbf{0 . 8 1 0}$ \\
\hline
\end{tabular}

Sources and notes: Data on expenditure types from Table 1. Age $65+=$ percentage of the population aged 65 years or over from Armingeon et al. (2006); Left $=$ Left parties total share of cabinet seats, 1960-2003, calculated from Armingeon et al. (2006); Catholic = percentage of the population baptised into the Roman Catholic faith from http://www.catholichierarchy.org/country/sc3.html; Imex = imports + exports as a percentage of GDP in 2003 from Heston et al. (2006); GDP growth = average rate of economic growth 1983-2003, from Heston et al. (2006); unemployment = rate of unemployment in 2003 from Armingeon et al. (2006). Figures in parentheses are t-statistics. ${ }^{*}$ Significant at the 0.1 level; ${ }^{* *}$ significant at the 0.05 level; ${ }^{* * *}$ significant at 0.01 level.

Table 3 reports findings for models consisting of these six variables for all four disaggregated spending areas as well as for total public social spending. A technical point of some importance is that, because all the models are constituted by the same six variables and because the four programme areas together constitute total spending, in each instance the reported regression coefficients for the programme areas are additively equivalent to the regression coefficient for total spending. This allows us to compare and contrast the effects of each independent variable on the different programme areas as well as to locate the different contribution of each to social spending as a whole.

A good vantage point for surveying the complex findings of Table 3 is by focusing initial attention on the model for spending as a whole. Looking only at aggregate expenditure as reported in the final column of Table 3 , the story that best seems to fit the facts as reported there is of a hugely significant Left partisan effect, modest but significant positive unemployment and external vulnerability effects and a marked negative impact of economic growth in shaping total expenditure outcomes. Together these four variables account for more than 80 per cent of the 
observed cross-national variation, with neither age structure nor religious faith apparently influencing outcomes to any significant degree. The key role of the Left, particularly in conjunction with negative economic growth effects, confirms recent findings (Castles, 2004, 2006; Castles and Obinger, 2007). However, the absence of significant age structure effects on age-related cash or health spending must be considered anomalous, given the prominence of this variable in both the industrialisation literature of the immediate post-war decades (see Wilensky, 1975) and in more recent speculations concerning the likely adverse expenditure effects of population ageing on government finances.

However, the account deriving from aggregate spending is immediately challenged when we examine the findings of the models for the separate programme areas. Age structure and religious faith explain nothing of overall spending, but, as the first column of Table 3 shows, they account for around twothirds of the variance in age-related cash expenditure. In both cases, the influence is positive, with each 1 per cent more of the population constituted by older people leading to a calculated 0.963 of GDP additional age-related spending and each 1 per cent more of those baptised into the Catholic faith translating into 0.046 of GDP additional age-related spending. Moreover, and quite extraordinarily, the findings in Table 3 appear to suggest that there is absolutely no overlap between the factors identified as shaping total spending and age-related spending, its largest single component.

The sources of these anomalous findings can only be properly understood by means of a contrast between the impact of population ageing and religious faith on age-related spending and on the other main components of social expenditure. In both instances, a significantly positive influence on age-related spending is offset by consistently negative impacts on working-age cash, health and other services. Not all these negative impacts are large or significant, but some are: age structure is strongly, significantly and inversely related to spending on the working-age population, and Catholicism is less strongly, but still significantly, inversely related to spending on caring services. This latter finding confirms aspects of the subsidiarity thesis. The former is suggestive of a potential mechanism driving a trade-off between age-related and working-age cash and a mechanism of some considerable future policy relevance in an era of rapid population ageing. Together, the effects, whether large or small, are sufficient to offset positive influences on age-related spending and to generate negligible coefficients for total spending.

The offsetting effects of age structure and religious faith are not the only reasons that the relationships between different expenditure areas are so relatively weak. Table 3 shows that the partisan complexion of government is a strong positive influence and economic growth a strong to modestly significant negative influence on both working-age cash and other services, while the relationships between these variables and age-related spending are negligible. These similarities 
in the factors shaping working-age cash and other services explain why we discover a significant and positive association between these expenditure types in Table 2, and the dissimilarity in the causal antecedents of age-related spending and these other types of expenditure why patterns of spending are, in general, so diverse. The dissimilarity among expenditure types is reinforced by the positive influence on working-age cash, but not on age-related spending or on other services, of both trade-related economic vulnerability and unemployment.

Table 3 affirms some prior hypotheses, refutes or at least partially disconfirms others and raises a variety of questions for further analysis. The speculation that the effect of economic vulnerability is via its impact on working-age cash is strongly confirmed as is the notion that this effect is via 'domestic compensation' rather than a 'race to the bottom'. So too is a contrast between the positive effects of Catholicism on cash spending on older people and its negative impact on service provision with, however, the caveat that the subsidiarity principle does not appear to lead to greater cash spending on those of working age. There remain important questions of why the strong positive influence of the Left and the nearly as strong negative influence of economic growth on both working-age cash and caring services do not extend to cash spending on older people. Arguably, the fact that the negative impact of economic growth is most strongly manifested in the area of working-age cash confirms the speculation of Castles and Obinger (2007) that this variable is as much a surrogate for social needs as an endogenous determinant of expenditure measures denominated in terms of GDP. There is also the question of why the age structure of the population has no discernible effect on the cross-national distribution of public health spending. More broadly, the question also arises of why the modelling exercise undertaken here is so relatively successful in accounting for the variance in age-related spending, working-age cash, other services and total spending, but is so utterly unsuccessful in accounting for variance in health spending. A possible explanation is that public health expenditure marches in tune to an entirely different drummer from other social expenditure types. More probably and as previously noted, the reason is that the cross-national variance of public health spending is now so limited that it is not susceptible to analysis using the simple cross-sectional regression methods on which the findings of Table 3 are based.

However, more than anything else, the findings contained in Table 3 affirm the need to go beyond the analysis of aggregate data to the underlying programme data of which it is constituted. Without separate programme data, we could read the evidence of an aggregate analysis as telling us that the age structure of the population and religious affiliation had no influence on welfare outcomes. Without such data we would be unaware of the strengths and weaknesses of the subsidiarity hypothesis or of a possible mechanism underlying a trade-off between different types of cash spending. Without such data we might assume, for want of better information, that the factors significant in shaping overall 
social expenditure were equally significant in shaping all categories of spending. More generally, without such disaggregated data, we would lack an important tool for unpacking what is going on beneath the surface of aggregate spending data. The 'black box' problem of locating the processes intervening between input and outcome variables in quantitative analysis is one of the most intractable in systematic comparative research (Goldthorpe, 1997). The opportunity of using the disaggregated programme data provided by SOCX as a key to unlocking the complexities of the factors driving social spending development is not one which should be rejected on the basis of admitted deficiencies in the only measure of welfare expenditure formerly available to us.

\section{Impacts on poverty and inequality}

We have shown that different types of social spending are differently distributed in different countries and families of nations and that the determinants of these expenditure types differ, often quite radically. However, if social expenditure distributions differ in character, the logic of comparison suggests that not only will their determinants be different, so too will be their effects. That being so, it also appears to follow that different expenditure types will differ - again, possibly, quite radically - in the extent to which they are conducive to goals consonant with whatever is taken as being the 'theoretical substance' of welfare states. In this section, we seek to assess the extent to which this is true of the expenditure categories focused on in this study by examining how far these categories are associated with distributional outcomes. The starting point of this chapter was Esping-Andersen's a priori assertion that 'not all expenditure counts equally'. Here, we address the issue empirically by asking whether some kinds of social expenditure count more than others in alleviating poverty and inequality.

Our test is simple and, in principle, incomplete. Space and, to some degree, data-incompleteness considerations preclude multivariate modelling of cross-national distributional outcomes, and our analysis here rests exclusively on bivariate findings. Two other considerations, however, somewhat mitigate this incompleteness. First, the strength of the correlations between at least one component of spending and measures of poverty and inequality is such as to suggest that this component would almost certainly be implicated in any multivariate modelling. Second, although the standard assumption of correlational analysis is that the causal arrow can go in both directions, that is actually empirically most unlikely in an analysis, which, as here, reveals a negative relationship between spending and redistribution. Unless the entire logic of a century or more of social intervention has been utterly mistaken, high levels of poverty and inequality seem hardly likely to turn out to be a stimulus to low levels of social spending. 
TABLE 4. Pearson's correlations between expenditure types, de-commodification, taxation incidence and redistributional outcomes

\begin{tabular}{lcccc}
\hline & $\begin{array}{c}\text { Gini } \\
\text { index }\end{array}$ & $\begin{array}{c}50 \% \text { median } \\
\text { population } \\
\text { poverty }\end{array}$ & $\begin{array}{c}50 \% \text { median } \\
\text { child poverty }\end{array}$ & $\begin{array}{c}50 \% \text { median } \\
\text { elderly } \\
\text { poverty }\end{array}$ \\
\hline Age-related expenditure & 0.094 & 0.010 & 0.020 & -0.051 \\
Working-age expenditure & $-0.865^{* *}$ & $-0.811^{* *}$ & $-0.83^{* *}$ & -0.442 \\
Health expenditure & -0.012 & -0.166 & -0.049 & -0.364 \\
Other service expenditure & $-0.547^{*}$ & $-0.52^{*}$ & $-0.601^{* *}$ & -0.410 \\
Total social expenditure & $-0.584^{* *}$ & $-0.649^{* *}$ & $-0.654^{* *}$ & $-0.498^{*}$ \\
De-commodification & $-0.762^{* *}$ & $-0.665^{* *}$ & $-0.705^{* *}$ & -0.454 \\
Taxation incidence & $-0.782^{* *}$ & $-0.754^{* *}$ & $-0.791^{* *}$ & -0.434 \\
\hline
\end{tabular}

Sources and notes: Data on expenditure types from Table 1. De-commodification $=2002$ figures for the de-commodification index in Scruggs (2004). Taxation incidence $=2001$ figures for public social expenditure taxation incidence from Castles and Obinger (2007). Figures for the Gini index and median poverty rates are from the latest waves of the Luxembourg Incomes Study (LIS) as reported online in mid-2007. Correlations for expenditure types are based on 19 cases; correlations for de-commodification and taxation incidence are based on 16 cases. ${ }^{*}$ Significant at the 0.05 level; ${ }^{* *}$ significant at the 0.01 level.

Table 4 reports correlations between the social expenditure measures identified in Table 1 above and measures of poverty and inequality taken from the Luxembourg Incomes Study (LIS) dataset. The inequality measure is the gini coefficient of inequality. The poverty measures include 50 per cent median population poverty, 50 per cent median child poverty and 50 per cent median elderly poverty. These measures come from the latest wave of poverty studies as reported in mid-2007, but the dates of individual country surveys do not necessarily correspond precisely with the 2003 data point for the OECD expenditure measures. Moreover, some of the countries in SOCX dataset are not to be found in the LIS dataset, so that the number of cases for each of the expenditure correlations is 19 rather than the 23 included in the analysis for previous tables (the missing countries are Iceland, Japan, New Zealand, and Portugal). The number of cases is further restricted - to 16 (further missing countries are Luxembourg, Greece and Spain) - in respect of two further variables included in Table 4 because they have been argued to be central to the welfare state's distributional role. One is the extent of social rights of citizenship measured here by de-commodification index scores (data from Scruggs, 2004). The other is public social expenditure taxation incidence (the extent of taxation on social spending), a variable which Castles and Obinger (2007) derive from Adema and Ladaique's (2005) decomposition of the SOCX dataset into a variety of measures of net rather than gross social spending, and which they argue constitutes a key mechanism of redistribution in modern welfare states. 
Table 4 demonstrates unequivocally that some types of social spending are, indeed, much more closely linked to distributional outcomes than others. In fact, neither age-related spending nor health expenditure is significantly associated with outcomes of any kind. Other service and total expenditure do co-vary moderately with the gini index and with both population and child poverty, and aggregate spending is the only measure to manifest an even modestly significant link with elderly poverty. However, it is working-age cash which is the expenditure category the most closely associated with distributional outcomes, with correlation coefficients for the gini index, population and child poverty all in excess of 0.8 . Moreover, these relationships are not just stronger than those for other expenditure types, but also modestly but consistently stronger than those for either the de-commodification index or public social expenditure taxation incidence. The story of Table 4, then, is that in respect of inequality and poverty other than that of older people, cash spending on those of working age counts for more than other types of expenditure or, for that matter, other imputed mechanisms of redistribution.

On reflection, these findings are scarcely counter-intuitive, although the fact that age-related cash spending appears wholly unrelated to outcomes does seem quite extraordinary. The obvious point, however, is that age-related cash spending is, today, focused more on horizontal life-cycle distribution than on vertical redistribution and, no less obviously, the main focus of public health spending is protection from catastrophic risk. Moreover, public health as well as pensions can, for the most part, be regarded as a savings scheme where the young healthy accrue benefits deferred until such time as they are older and less healthy. In other words, because the purposes of these programmes are not exclusively about modifying vertical inequalities, their effects are less related to the achievement of such goals. In contrast, other services and working-age cash spending are, to some considerable degree, directed at ameliorating vertical inequalities: other services by providing free or subsidised provision on the basis of need, and working-age cash by supplying income to those who, for whatever reasons, are without adequate financial support. Savings schemes covering the needs of those of working age are necessarily less effective than those setting aside income for use when one is older because, in the case of the former, expenditure cannot readily be deferred until such time as funds are available. In respect of the income needs of those of working age, the state is generally the provider of first and last resort, and so it is those states which provide most resources to cater to these needs that turn out to achieve most in reducing poverty and inequality.

Finally, we address the question of why working-age cash expenditure appears more directly related to poverty and inequality than either taxation incidence or de-commodification scores. In respect of taxation incidence, the answer is probably that the account in Castles and Obinger (2007) is incomplete. High levels of taxation on benefits provide only one of two mechanisms for 
achieving distributional outcomes. Such taxation directly modifies the income distribution by levying additional taxes on better-off members of a society, thereby directly reducing their incomes. However, it also has a further indirect effect of creating a pool of additional resources for funding benefits with no in-built savings incentives. In other words, public social expenditure taxation incidence is an important mechanism for funding working-age cash expenditure, and it is this latter variable that impacts directly on raising the incomes of the poor. Once again, we would claim, as we claimed in respect of the determinants of expenditure types, that a disaggregated approach is a valuable key to a better understanding of what goes on in the 'black box' of the policy process.

In respect of the de-commodification index, one possible answer is that these index scores are partly constituted by pension replacement rates and hence capture aspects of horizontal as well as vertical redistribution. However, recalculating de-commodification scores excluding the pensions' element only marginally improves their fit with distributional outcomes and never so as to challenge the explanatory primacy of working-age cash. Protagonists of the decommodification index may, of course, defend the measure on the grounds that social rights encompass much more than simply distributional outcomes. It may be regarded as significant, however, that a disaggregated measure of social expenditure tells us more about such outcomes than a measure explicitly devised to address the problems arising from comparisons of aggregate spending. We see this as vindication of the view that, given the now ready availability of programme data, expenditure disaggregation is the most obvious route forward in establishing not only the variety of what welfare states do but also the determinants and the outcomes of such interventions.

We conclude simply by saying that, if one's motivation in studying social policy is to do something about poverty and inequality, the findings of this study suggest that the action is in the area of cash provision to those of working age. That has been the primary focus of much of Stephan Leibfried's research during recent decades, and this commentator for one commends him for it.

\section{Notes}

1 A slightly different version of this article is to be published in German as a contribution to a Festschrift for Professor Stephan Leibfried, Director of the Centre for Social Policy at the University of Bremen.

2 The expenditure disaggregation previously proposed in Castles (2002) suggests a threefold categorisation into income-replacing expenditure, contingency-based expenditure and state expenditure. The last of these corresponds almost precisely with the OECD category of other service expenditure. The income-replacing category cuts across the age-related/working-age cash divide now proposed by the OECD, while the contingency-based category includes health spending along with cash spending on unemployment, housing and social assistance. 
The OECD's present classification is to be preferred both because it is more functionally specific and because the OECD now provides the necessary data breakdown on, what it is to be hoped will be, a routine basis.

\section{References}

Adema, W. and Ladaique, M. (2005), Net Social Expenditure, 2005 Edition: More Comprehensive Measures of Social Support, OECD Social, Employment and Migration Working Papers No. 29, Paris: OECD.

Armingeon, K., Leimgruber, P., Beyeler, M. and Menegale, S. (2006), 'Comparative political data set 1960-2004', Institute of Political Science, University of Berne.

Buhr, P. and Leibfried, S. (1995), "What a difference a day makes": the significance for social policy of the duration of social assistance receipt', in G. Room (ed.), Beyond the Threshold: The Measurement and Analysis of Social Exclusion, Bristol: Policy Press.

Castles, F. G. (1994), 'Is expenditure enough? On the nature of the dependent variable in comparative public policy analysis', Journal of Commonwealth and Comparative Politics, 33: 3, 349-63.

Castles, F. G. (1995), 'Welfare state development in Southern Europe', West European Politics, 18: 2, 291-313.

Castles, F. G. (1998), Comparative Public Policy: Patterns of Post-war Transformation, Cheltenham: Edward Elgar.

Castles, F. G. (2002), 'Developing new measures of welfare state change and reform', European Journal of Political Research, 41: 613-41.

Castles, F. G. (2004), The Future of the Welfare State, Oxford: Oxford University Press.

Castles, F. G. (2006), 'The growth of the post-war public expenditure state: long-term trajectories and recent trends', TranState Working Paper No 35, Bremen University.

Castles, F. G. and Obinger, H. (2007), 'Social expenditure and the politics of redistribution', Journal of European Social Policy, 17: 3, 206-22.

Esping-Andersen, G. (1990), The Three Worlds of Welfare Capitalism, Cambridge: Polity Press.

Esping-Andersen, G. (1993), 'Budgets and democracy: towards a welfare state in Spain and Portugal, 1960-1986', in I. Budge and D. McKay (eds.), Expanding Democracy: Research in Honour of Jean Blondel, London: Sage.

Ferrera, M. (1996), 'The "southern model" of welfare in social Europe', Journal of European Social Policy, 6: 1, 17-37.

Goldthorpe, J. (1997), 'Current issues in comparative macrosociology: a debate on methodological issues', Cognitive Social Research, 16: 1-26.

Heston, A., Summers, R. and Aten, B. (2006), Penn World Table Version 6.2, Center for International Comparisons of Production, Income and Prices at the University of Pennsylvania.

Huber, E. and Stephens, J. (2001), Development and the Crisis of the Welfare State, Chicago: University of Chicago Press.

Katzenstein, P. (1985), Small States in World Markets, Ithaca: Cornell University Press.

Kittel, B. (1999), 'Sense and sensitivity in pooled analysis of political data', European Journal of Political Research, 35: 225-53.

Leibfried, S. (1993), 'Towards a European welfare state?', in C. Jones (ed.), New Perspectives on the Welfare State in Europe, London: Routledge.

Leisering, L. and Leibfried, S. (1999), Time and Poverty in Welfare States: United Germany in Perspective, Cambridge: Cambridge University Press.

Luxembourg Income Study (LIS) (2007), Key Figures, Accessed at http://www. lisproject.org/keyfigures.htm, May 2007.

Myles, J. and Quadagno, J. (2002), 'Political theories of the welfare state', Social Science Review, March: 34-57.

OECD (1996), Social Expenditure Statistics of OECD Member Countries (Provisional Version), Paris: OECD. 
OECD (2007a), OECD Social Expenditure Database, 1980-2003, Paris: OECD.

OECD (2007b), The Social Expenditure Database: An Interpretative Guide, Paris: OECD.

Schmidt, M. (1996), 'When parties matter: a review of the possibilities and limits of partisan influence on public policy', European Journal of Political Research, 30: 2, 155-83.

Scruggs, L. (2004), Welfare State Entitlements Data Set: A Comparative Institutional Analysis of Eighteen Welfare States, Version 1.1, Storrs: University of Connecticut.

Taylor-Gooby, P. (ed.) (2004), New Risks, New Welfare: The Transformation of the European Welfare State, Oxford: Oxford University Press.

Titmuss, R. (1950), Problems of Social Policy, London: HMSO \& Longmans Green.

Van Kersbergen, K. (1995), Social Capitalism: A Study of Christian Democracy and the Welfare State, London: Routledge.

Wilensky, H. (1975), The Welfare State and Equality, Berkeley, CA: University of California Press. 